\title{
Courtship Behaviour of Short-eared Owl
}

by Ralph D. Carson, Sask. Museum of Natural History, Regina

During the late evening of May 18, 1961, while Dr. R. Nero and I were returning from a field trip in southern Saskatchewan we observed an exciting aerial performance by two Short-eared Owls (Asio flammeus), a display which is apparently a part of their courtship behaviour. Current behavioural literature shows that very little has been published on the displays of owls, hence the significance of reporting chance observations.

We were travelling along Highway No. 13 near Ogema when we suddenly glimpsed two Short-eared Owls flying about a stubble field in the rapidly fading light. We could see one owl making short stoops beyond a rise at what we surmised was a predator on the owl's territory. As we drove closer to the scene we could see a pattern in the flight of both birds and after shutting the engine off we could clearly hear the "wing-clapping" of an owl in courtship flight. Both owls were rapidly circling with steady wing beats over a small portion of the field at a height of about 25 feet. Each owl was flying in a separate circular pattern which occasionally brought them side by side. After intervals of circling two or three times one of the owls, which we assumed was the male, would make a short, slanting dive to a particular spot in the field (potential nest site?), bringing his wings down and
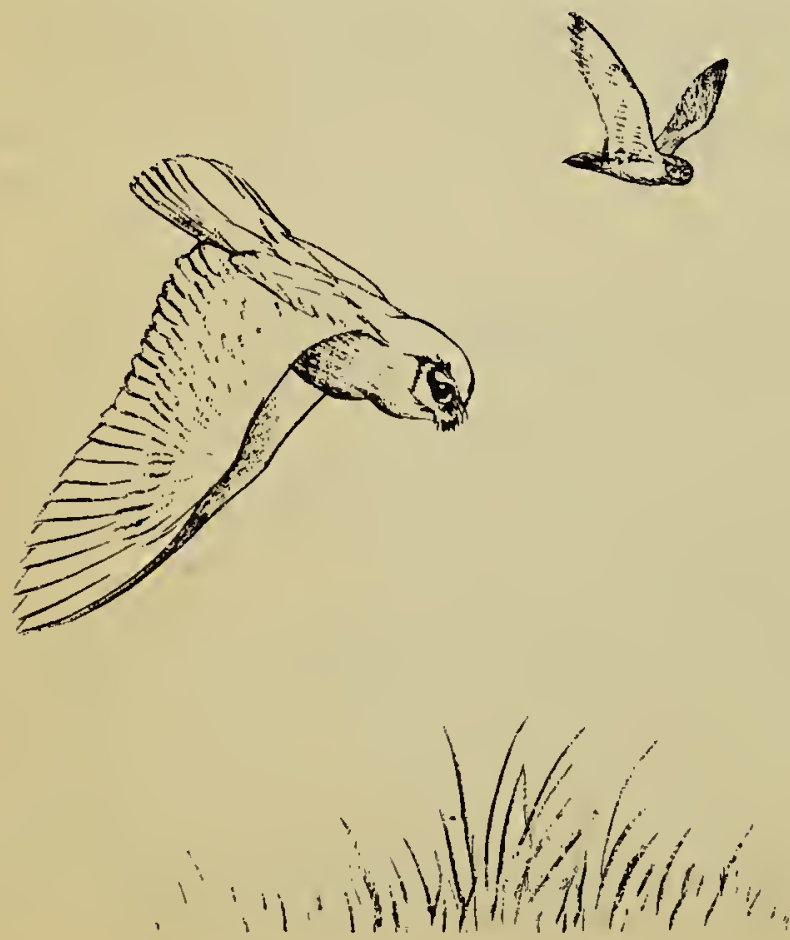

rapidly striking them together, thus producing an astonishing burst of clapping sound. This clapping lasted about two seconds and was clearly audible to us each time it was given although we were about 400 feet or more away.

Following a series of wing-clapping dives the male would rush toward the presumed female, the latter would swing about to meet his approach and, just before it seemed that they would collide, they would suddenly thrust out their feet, grasp each other's feet and then, with flailing wings and still clinging together, fall to earth with a spinning motion. The spinning motion seemed to result from the momentum of the rush rather than an attempt on their part to fly in such an extraordinary fashion. In one occurrence, one of the owls seemed to lose its balance as they struck together and it quite tumbled over backwards. Again, we assumed that this was caused by the momentum of the male's flight. This "spinning-fall" act was repeated three or four times in the few minutes that we were watching the birds. Afterwards, the owls would immediately take flight and begin to circle again in their respective flight paths, and the male would again resume his wing-clapping dives. We watched this remarkable performance right up to the end. About ten minutes after our arrival on the scene the female alighted on the stubble; the male made several stoops at her, apparently in an effort to excite her into further action, but she showed no response and the male then settled on the ground at some distance.

Arthur C. Bent, in Life Histories of North American Birds of Prey, Part II, 1938, pp. 169-170, quotes observations of the courtship flight and "song" of the Short-eared Owl as recorded by A. D. DuBois, Francis Harper, and Edward A. Preble. DuBois and Harper observed courtship flight, including the wingclapping, but at great heights - as much as several hundred feet. Moreover, only single birds were involved and nothing comparable to the above observation seems to have been reported. 